\title{
“ThE MOST HIGH DOES NOT DWELL IN HOUSES MADE WITH HUMAN HANDS": A STUDY OF POSSIBLE HELLENISTIC JEWISH PARALLELS FOR THE JERUSALEM TEMPLE AS IDOLATRY IN ACTS $7: 48$
}

\author{
“O ALTİSSIMO NÃO HABITA EM OBRAS DE MÃOS HUMANAS": UM ESTUDO DE \\ POSSÍVEIS PARALELOS JUDAICO-HELENÍSTICOS PARA O TEMPLO DE JERUSALÉM \\ COMO IDOLATRIA EM ATOS DOS APÓSTOLOS 7:48
}

Monica Selvatici ${ }^{1}$

\section{RESUMO}

O propósito do presente artigo é duplo. (1) Ele busca analisar o discurso de Estevão, uma passagem controversa no capítulo 7 do livro neotestamentário Atos dos Apóstolos. Nele, Estevão, um judeu cristão helenista, critica o templo de Jerusalém ao argumentar que "o Altíssimo não habita em obras de mãos humanas (cheiropoiētos)" (At. 7:48). O uso do termo pejorativo cheiropoiētos para designar o templo judaico constituía uma blasfêmia na medida em que, no período anterior à produção dos textos do Novo Testamento, este termo fora usado na Bíblia hebraica somente para templos e estátuas de divindades politeístas, os chamados 'ídolos'. (2) Uma vez que o discurso de Estevão parece recuperar certo material histórico, o artigo, então, examina textos judaico-helenísticos escritos entre o século I a.C. e o século I d.C. e que apresentam menções negativas ao Templo de Jerusalém de forma a situar historicamente a crítica de Estevão em Atos 7:48.

Palavras-chave: Judaísmo helenístico - Atos dos Apóstolos - Templo de Jerusalém - Estevão - idolatria

\section{ABSTRACT}

The purpose of the present article is twofold. (1) It analyzes Stephen's speech, a controversial New Testament passage in the book of Acts chapter 7. In it, Stephen, a Hellenist Christian Jew, criticizes the Jerusalem temple arguing that "the Most High does not dwell in houses made with human hands (cheiropoiētois)" (Acts 7:48). Calling the temple a cheiropoiētos was considered blasphemy once prior to the New Testament that term was only used for idols/false gods in the Hebrew Bible. (2) As Stephen's speech seems to recover historical material, the article, then, examines Hellenistic Jewish texts written around 1st century BCE and 1st century CE which present negative references to the Jerusalem Temple in

1 Departamento de História - Universidade Estadual de Londrina - UE 
order to reconstruct a plausible Hellenistic Jewish background for Acts 7:48.

Keyword: Hellenistic Judaism - Acts of the Apostles - Jerusalem temple -Stephen - idolatry

\section{Introduction:}

This article examines negative references to the Jerusalem temple in Hellenistic Jewish texts written around $1^{\text {st }}$ century $\mathrm{BCE}$ and $1^{\text {st }}$ century CE. The purpose of the analysis is the reconstruction of a plausible Hellenistic Jewish background for the controversial New Testament passage (or better, a whole speech) in the book of Acts of the Apostles. In it, Stephen, a Hellenist Christian Jew, criticizes the Jerusalem temple arguing that "the Most High does not dwell in houses made with human hands (cheiropoiētois)" (Acts 7:48). Calling the temple a cheiropoiettos ${ }^{2}$ was an insult once prior to the New Testament that term was only used for idols / false gods in the Hebrew Bible.

The book of Acts, written in the end of the $1^{\text {st }}$ century CE, is intended to be a source of deeds of the apostles and a historical account of the spread of the Christian Good News "in all Judea and Samaria, and to the ends of earth" (Acts 1:8). It is commonly attributed to Luke, a disciple of Paul the apostle, and is, surely, a continuation of the account of the third gospel once the author intended it to be a two-volume work.

The first half of the book of Acts is dedicated to the narration of how the primitive Church was first organized in Jerusalem and to the conversions and miraculous deeds by the apostles, in special, those accomplished by Peter. The second half of the book focuses on the spread of the Christian message outside Palestine, through the efforts of Paul of Tarsus, a former Pharisee converted to the Christian group in a radical way by a vision of the Risen Christ - carefully depicted, with minor disagreements, three times in the book (Acts 9:3-9; 22:5-16; 26:9-18). The development of the expansion of the Good News by Paul is construed in two phases by the book's author: one first movement towards Diaspora Jews (and, accidentally, also some Gentile God-fearers) in the local synagogues of the Mediterranean cities and a final and radical change to Mediterranean Gentiles only after the continuous rejection of the message by the Jews. Beverly R. Gaventa (1988, p. 150) rightly points out that:

The theology of Luke is intricately and irreversibly bound up with the story he tells and cannot be separated from it. An attempt to do justice

\footnotetext{
${ }^{2}$ The terms in Greek have been transliterated in order to avoid printing problems.
} 
to the theology of Acts must struggle to reclaim the character of Acts as a narrative.

Speeches are important key elements in the book of Acts for they more explicitly demonstrate the author's intention. According to Fitzmyer (1998, p. 105), "the main question that speeches raise is their historicity. In the form we have the speeches in Acts they are clearly Lucan compositions". They occupy almost a third of the book (about 295 verses out of 1000). Particularly, Stephen's speech is the longest for it covers a whole chapter (Acts 7:2-53). Fitzmyer (1998, p. 104) classifies the speech, in terms of genre, as a 'prophetic indictment' and its content does not seem to fit the whole account of the book.

If one reads the whole text of Acts, one notices that, apart from the explicit criticism of idolatry in Stephen's speech, the Jerusalem temple is otherwise depicted in a very flattering way by Luke. That constitutes a problem for it is difficult for scholars to identify if Luke (and, especially, the early Christians whose story he claims to tell) regarded the temple as something good or something bad. The most paradoxical passages are those involving Stephen himself. In Acts 7:48, his words are: "the Most High does not live in houses made with human hands". However, before his speech and just like in the account of Jesus' trial in Mark 14:55-59 and Matthew 26:59-61 (a passage that Luke intentionally omits), the accusation that Stephen has spoken "blasphemous words against Moses and God" (Acts 6:11) is first made by 'false witnesses' (te márturas pseudeĩs - 6:13). Luke's omission in the gospel must be explained by his later usage in Acts of the same pattern in Stephen's 'trial' before the Sanhedrin.

Evidence of a good depiction of the Jerusalem temple is found everywhere else in the book of Acts. In fact, there are more references to the temple in Acts than in all four gospels. And in the gospel of Luke there are more references to the temple than in any other gospel. From that information, one infers that the Jerusalem temple must have been a major issue for Luke.

Earlier in the book of Acts, we are told that:

1)the Christians constantly attend the temple (2:46);

2)Peter and John go up to the temple at the afternoon hour of prayer (3:1);

3)Peter and John are inside the temple courtyard - reference to the Beautiful Gate (3:2, 10) and to Solomon's Portico (3:11);

4)Peter and John are arrested by the Jewish authorities and, among them, the person responsible for the public order in the temple - ho stratēgòs toũ hieroũ (4:1); 
5) Peter and John are before the Sanhedrin - which usually met in a room in the temple, according to Josephus in The Jewish War 5.144 - (4:5-22). Later on, all of the apostles are brought before the Sanhedrin (5:27-41);

6) "They were all together in Solomon's Portico", probably not only the apostles but the whole of the disciples (5:12-14). The temple courtyard is frequently used as a place of prayer and speeches by the apostles according to Acts (see: 5:25-6).

After the events that lead to Stephen's stoning and death (his preaching in the Hellenist synagogue, the false witnesses' accusation, his speech before the Sanhedrin), the temple is mentioned regarding the events related to Paul in Jerusalem. Again, the view of the temple as a holy place is persistent:

7)-Paul arrives in Jerusalem in the middle of rumors that he had been teaching apostasy from Judaism. In order to reverse the situation, he is told by the members of the Church to meet the expenses of the purification of four men and the sacrifices they are supposed to offer at the temple. He purifies himself and takes them to the temple (21:17-26). That does not seem to resolve the issue for he is, then, accused of bringing a Gentile into the temple complex. Luke tries desperately to defend the apostle against that charge (21:27-9) - a crime that Paul must probably have committed;

In order to search for evidence of the existence of similar opinions, in Hellenistic Jewish texts, to the one expressed in the speech of Stephen on the matter of the Jerusalem temple, it is necessary first to take a closer look at the speech itself and, by its whole context, try to better grasp the view behind the sentence "God does not dwell in houses made with hands".

The speech before the Sanhedrin takes place by reason of accusations against Stephen by false witnesses (as presented above) that claim that (1) he had been saying "blasphemous words against Moses and God" (6:11) and, two verses later, that (2) he had been speaking "against this Holy place and the Law" (6:13). ${ }^{3}$ It seems that Moses stands for the Law as well as God stands for 'this Holy place'.

The connection Moses/Law looks very clear, although in the speech itself Stephen never criticizes Moses, but speaks of him in a very favorable way, as a predecessor of Jesus, as a "ruler and liberator" (7:35). The connection God/temple becomes clear when, later in the speech, while Stephen retells, in his own (or Luke's) point of view, the history of the Jewish people from Abraham to Moses, then David and Solomon:

\footnotetext{
${ }^{3}$ By reason of our argumentation, the third charge laid by the false witnesses on Stephen, that he claimed that "Jesus the Nazorean will destroy this place and change the customs that Moses handed down to us" (6:14) will not be analyzed together with the first two ones because it deals only indirectly with the nature of the temple for Jews. It will be recapitulated in the conclusion of the article.
} 
It was this Moses whom they rejected ... and whom God now sent as both ruler and liberator ... He led them out, having performed wonders and signs in Egypt, at the Red Sea, and in the wilderness for forty years. This is the Moses who said to the Israelites, 'God will raise up a prophet for you from your own people as he raised me up.' ... Our ancestors were unwilling to obey him; instead, they pushed him aside, and in their hearts they turned back to Egypt, saying to Aaron, 'Make gods for us who will lead the way for us...' At that time they made a calf, offered a sacrifice to the idol, and reveled in the works of their hands ... Our ancestors had the tent of testimony in the wilderness, as God directed when he spoke to Moses, ordering him to make it according to the pattern he had seen. Our ancestors in turn brought it in with Joshua when they dispossessed the nations that God drove out before our ancestors. And it was there until the time of David, who found favor with God and asked that he might find a dwelling place for the house of Jacob. But it was Solomon who built a house for him. Yet the Most High does not dwell in houses made with human hands; as the prophet says, 'Heaven is my throne, and the earth is my footstool. What kind of house will you build for me, says the Lord, or what is the place of my rest? Did not my hand make all these things?' (Acts 7:35-41, 44-50. Bold text added)

The tabernacle was the tent which had been built according to God's instructions to keep the Shekinah (in Jewish belief, the "presence" of God in a locality) safe and visible during the Jews' journey through the desert up to the Holy Land. The temple erected by Solomon, the accomplishment of his father's will, was a palace built to replace the tent under which the presence of God was to be found. God and temple were, then, supposed to be directly related. According to Stephen, though, God was present in the poor tabernacle but when Solomon built him a beautiful house and the Jews "reveled in the works of their hands" (verse 41 mentioned a couple of verses earlier regarding the golden lamb should be echoing in the mind of Luke's audience), God would no longer be there for he "does not dwell in houses made with human hands". The Lord himself explains by way of the prophet Isaiah 66:1-2: "What kind of house will you build for me, or what is the place of my rest? Did not my hand make all these things?" 
The shocking statement concerning the Jerusalem temple in Stephen's lips is, later in the account of Acts, better explained. In Paul's preaching at the Athenian Areopagus, he tries to persuade the Athenians that the 'unknown god' to whom one of the many altars in the city is dedicated is actually the true God, the Most High. In fact, this is the only Pauline speech narrated by Luke in which the apostle brings pagan elements to make his audience identify with his proclamation:

\begin{abstract}
Athenians! ... as I went through the city and looked carefully at the objects of your worship, I found among them an altar with the inscription:: 'To an Unknown god'. What therefore you worship as unknown, this I proclaim you. (Acts 17:22-3)
\end{abstract}

In Acts 17:24-5, the term 'made by hands' (referring to 'shrines ${ }^{4}$ made by human hands' cheiropoiētois naoĩs) is used once again:

The God who made the world and everything in it, he who is Lord of heaven and earth, does not live in shrines made by human hands, nor is he served by human hands, as though he needed anything, since he himself gives to all mortals life and breath and all things... Well, if we are of a divine breed, we cannot think that the divinity is similar to gold, silver or to stones, to an art sculpture or human made (Acts 17:24-5, 29; see Isa. 66:1-2. Bold text added)

Apparently in its context the term simply refers to pagan temples in Athens (or in the pagan world, in general). Paul would, then, be inspired by the ancient theme of anti-idolatry propaganda found in the prophet Isaiah (40:20ff). However, the similarities with Stephen's speech are very strong and seem intentional on the part of Luke, especially, when he makes Paul stress the fact that God does not dwell in shrines/temples (naois) made by human hands. As Paul had not mentioned naoĩs and only objects of worship and altars, it becomes difficult to think of a naïve coincidental presentation by Luke. Charles K. Barrett, in his commentary on the book of Acts, is, though, very careful not to precipitate any conclusion

\footnotetext{
4 'Shrines' is the term chosen by the editors of the HarperCollins Study Bible (NRSV) because it is a consensus that Paul, in his speech at the Areopagus, is talking about pagan temples and not the temple in Jerusalem. However, as the term in Greek is naoĩs, it may well be translated as 'temples'.
} 
on this matter. He leaves the questions unanswered: "Did Luke notice this? Did he take the argument to be limited strictly to its immediate setting?" (1991, p. 354). More recently, Steve Smith, employing a narrative approach to Luke-Acts, becomes certain of Luke's theological purposes when narrating Stephen's speech and trial. Without hesitation, Smith (2017, p. 191) asserts: "This description of idolatry is a significant development in Acts 7 through its focus on the golden calf incident as the rejection of God in favour of false deities of their own creation (Acts 7.39-41)".

Trying to point towards a brief conclusion, the important thing to do is remember the purpose of the text for Luke, that is, to teach a specific audience about Christianity. Bearing that in mind, it seems very correct to argue like Joseph Fitzmyer ${ }^{5}$ that both speeches (Stephen's and Paul's) do fit a larger scheme in Luke's thought, that is:

(1) The temple in Jerusalem is to be respected as the main Jewish institution because it had been so regarded for centuries in Judaism (so, the apostles go there to preach and, later, Paul purifies himself to enter it);

(2) Paradoxically, the temple is not to be the cult core for Christianity for God is not present there anymore. The Jews understood it incorrectly when they built a marvelous palace and reveled in the work of their hands. They ended up equaling the shrine to - if one pushes the argument far enough - the Parthenon, for instance. In sum, the temple may be referred to like any other temple dedicated to idols made by human hands.

The fact that Stephen's speech definitely fits a larger purpose in Luke's thought in no way prevents the event from being historical. Although William D. Davies is skeptical about Stephen having spoken the speech of Acts 7 , he believes that the speech "recovers great historical value as a document of that sector of Judaism from which Stephen and his colleagues are said to have come" (apud BARRETT, 1994, p. 339). In fact, it is very plausible to argue like C. K. Barrett that "the corporate memory of the mixed Jewish and Gentile church of Antioch provided the framework" (1994, p. 339) for the long speech Luke specially created to fit Stephen's lips. Even J. Fitzmyer, who is very cautions in attributing the speech to a defined Hellenistic Jewish source, admits that because Stephen's picture of the temple is not entirely that of Luke, we must assume "that at least some details of Stephen's speech have been inherited by Luke from a preexisting source" (1998, p. 368). Stephen must, then, have said something very negative about the Jerusalem temple for he was later stoned to death and, according to the book of Acts, his group had to flee from persecution in Judea. The use of the term cheiropoiettos to describe the holy sanctuary in Jerusalem would fit well the severe punishment.

${ }^{5}$ Fitzmyer (1998, p. 356) argues: "Stephen's speech will enable Luke to formulate clearly the position of Christianity visà-vis Judaism before the Jerusalem religious authorities". Concerning Paul's speech, the author (1998, p. 602-3) affirms: "One should also note the Lucan buildup in Acts for this speech. Its remote context can be seen in the promise in 2:39; in the promise in 3:25; in what Stephen asserts in 7:48; in what Peter affirms in 10:34; in James's agreement in 15:14" (bold text added). 
In the Hebrew bible, we find evidence of a questioning of the temple holiness. In 1 Kings 8:27, we have the following questions: "But will God indeed dwell on the earth? Even heaven and the highest heaven of heavens cannot contain you, much less this house that I have built!". And again in 2 Chronicles 6:18, "But will God indeed reside with mortals on earth? Even heaven and the highest heaven cannot contain you, how much less this house that I have built!". One of the striking features of Stephen's criticism of the temple is the very small number of parallels for it in Jewish literature of the time (I BCE - I CE) when the episode occurred, as assumed, in the 30s CE. C. K. Barrett even denies that there were any parallels to such "disrespect of the temple, for even the Qumran sect did not reject the temple and its sacrifices" (1994, p. 338). For him, the existence of synagogues in Jerusalem is the only piece of evidence of a supposed trend in early Judaism not completely satisfied with the temple cult.

We should, therefore, analyze Hellenistic Jewish texts in which we encounter a different opinion (rejection/criticism or allegorizing of the temple cult) from the common and widespread praise of the Jerusalem shrine. Among Hellenistic Jewish texts, we find evidence of a peculiar or negative depiction of the Jerusalem temple in three different sources: Philo of Alexandria, the fourth Sibylline Oracle and the epistles of Pseudo-Heraclitus.

\section{Philo of Alexandria}

One of the most important sources (if not the most significant one) in Hellenistic Jewish texts of a spiritualized view of the Jerusalem temple is Philo of Alexandria - who lived at the beginning of the $1^{\text {st }}$ century CE. He was an important member of the Jewish community in the city of Alexandria, Egypt, who came from a rich family that had many connections with the imperial power: his brother and his nephew played important roles in the political life of Alexandria (HADAS-LEBEL, 2012, p. 27-31).

Certainly, Philo's wealthy condition allowed him to survive the $1^{\text {st }}$ century CE major incident at Alexandria involving the Jewish community: the revolt of $38 \mathrm{CE}$ in which the brief passage of the Jewish king Agrippa by the city on his way from Rome back to Palestine and his very warm welcome by Alexandrian Jews fostered a violent reaction of the gentile population against the Jews. Agrippa's visit was 'the spark in the powder keg' of Alexandrian relations between Jews, Greeks and Egyptians, which had grown harsher because of issues concerning citizenship in the Roman Empire. 
Probably, the wealth of his family also helped his many texts (historical and, mainly, philosophical treatises and allegories) survive throughout history. Later on, they were appropriated by Christians and used for their own purposes. Josephus is the only other Jewish author whose work length parallels that of Philo.

In Philo's opinion, philosophy constituted the best tool in the work of interpreting the Torah. For that, he is known to be the first ancient author to blend Hellenistic philosophy with Jewish tradition, later something very much practiced among the Church Fathers.

Philo's most peculiar feature in terms of the relation between Judaism and the so-called Hellenism was his ability to easily interact with the highly Hellenized environment of Alexandria. He may have been a citizen of Alexandria and may have attended the ephebate in the gymnasium for his mastery of the Greek language, philosophy and education, in general, accounts for that. Martin Hengel, in his landmark study Judaism and Hellenism, believes that only the frequentation of such Greek schools would explain "the remarkable and probable unique fusion in the history of Jewish and Hellenistic culture from the third century [BCE] on, in Alexandria" (HENGEL, 1974, vol. I, p. 66). However, more recently, Mireille Hadas-Lebel has refuted this former consensus on the matter of Philo's education when she stated that:

It would appear, (...), that those schools, which were originally open to all children of well-to-do families without distinction of origin, would have accepted only Greeks in Philo's time, as a result of the decrees of Augustus who aimed at promoting Greeks over other populations of Egypt". (HADAS-LEBEL, 2012, p. 55)

In any case, Philo can be interpreted as an example of the social behavior of the Jewish elite in Alexandria. But when it came to the following of the Jewish ritual, Philo was a fairly zealous observant. Speaking in theoretical terms, despite his acculturation, Philo was not assimilated to the Hellenistic environment (BARCLAY, 1996, p. 158-63). On the contrary, he was faithful to his Jewish community in Alexandria and to the temple in Jerusalem. He showed his loyalty to both of them in his work Legatio ad Gaium (156ff; 184ff; 191ff; 281ff; 356ff), dedicated to the account of the Jewish embassy he led to Rome after the events of 38 CE.

Philo's attitude towards the Jerusalem temple comprehended two different aspects: the idea of the temple as an allegory of spiritual worship and true respect for its earthly role. 
Concerning the first aspect, he developed the notion of the temple as a heavenly shrine or as the whole universe. He explains in De Specialibus Legibus I, 66:

The highest, and in the truest sense the holy, temple of God is, as we must believe, the whole universe, having for its sanctuary the most sacred part of all existence, even heaven, for its votive ornaments the stars, for its priests the angels who are servitors to His powers..

Karl-Gustav Sandelin, reviewing P. V. Legarth's book on temple symbolism and Christology in Ignatius of Antioch's thought, points out that for Legarth "the temple cult and the priesthood play important roles in the writings of Philo. The priesthood is either idealized or spiritualized like the idea of the temple" (2000, p. 167). Even Man's mind can be seen as the temple of God. According to Sandelin (2000, p. 167), Legarth notices, however, that Philo never reflects on the new temple nor does he see the Messiah as a temple-builder. Instead, he allegorizes the temple to fit his philosophical explanations/justifications of the history and traditions of Israel. In the philosophical domain, modern scholars, like Margaret Barker, ask themselves if the temple imagery in Philo would be an indication of the origin of the Logos once His Logos has always been a perennial problem (BARKER, 1991, p. 70-102).

Concerning the second aspect of Philo's attitude toward the temple, his historical texts, such as Legatio ad Gaium and In Flaccum, surely reveal his concrete behavior towards the desecration of the temple. Instead, we choose here one of his philosophical texts to show how much respect and how little reflection he presents in terms of the role of the real sanctuary in Jerusalem. In De Vita Mosis II, Philo argues that Moses' life comprehended three main aspects: the royal, the legislative and the one concerning his priesthood. Regarding Moses' priesthood, Philo says that:

this privilege, a blessing which nothing in the world can surpass, was given to him [Moses] as he due, and oracles instructed him in all that pertains to rites of worship and the sacred tasks of his ministry (67) ... While he was still staying on the mount, he was being instructed at all the mysteries of his priestly duties: and first in those which stood first in order, namely the building and furnishing of the sanctuary. Now if they had already occupied the land into which they were removing, they would necessarily have had to erect a magnificent temple on the most open and conspicuous site, with costly stones for its material, 
and build great walls around it, with plenty of houses for the attendants, and call the place the holy city. But, as they were still wandering in the desert and had as yet no settled habitation, it suited them to have a portable sanctuary, so that during their journeys and encampment they might bring their sacrifices to it and perform all their other religious duties, not lacking anything which dwellers in cities should have. It was determined, therefore, to fashion a tabernacle, a work of the highest sanctity, the construction of which was set forth to Moses on the mount by divine pronouncements" (71-5. Bold text added).

By the passage in bold letters, we can assume that Philo never questioned the necessity of a 'magnificent temple' for the glory of the Most High. His explanation for the tabernacle is a practical one - "as they were still wandering in the desert and had as yet no settled habitation, it suited them to have a portable sanctuary"6 - and is very different from the story Stephen tells. While Stephen emphasizes the sanctity of the Tabernacle built under God's instructions, Philo understands it as a temporary building.

\section{The Fourth Book of the Sibylline Oracles}

The group of Old Testament pseudepigraphic writings known as sibylline oracles is originally a collection of Jewish texts which, in the shape of oracles pronounced by a pagan Sibyl, ${ }^{7}$ was used for apologetic purposes and political propaganda. According to Erich Gruen (1998, p. 268-9), "Jews were assiduous in exhibiting the superiority of their faith and nation through usurpation of pagan conventions. The practice took a multitude of forms. None, however, was more dramatic than commandeering the voice of the Sibyl".

Twelve (or, perhaps, fourteen) sibylline oracles have survived from Antiquity to us and they are all very characteristic for they bear a superficial language. They were collected in the $6^{\text {th }}$ century CE. Many Christian interpolations have been found in such texts. The principle for distinguishing Christian from Jewish material turned out to be an easy one: Christians often left their Christian material very explicit, so when there is no explicit

\footnotetext{
${ }^{6}$ Bold text added.

${ }^{7}$ In Greco-Roman culture a woman who prophesized in ecstatic state.
} 
Christian trait, it can be assumed that the text is Jewish. The general agreement is that, at least, books III, IV and V are of Jewish origin and that the other Christian works have Jewish substrata.

The Jewish sibylline oracles depict the Jerusalem temple in a rather paradoxical way. While books III and V refer to the temple in a very flattering way, book IV criticizes either the one temple in Jerusalem or temples, in general, in a harsh way.

Scholars date the controversial third Sibyl, which is considered to be the earliest one, either from the $1^{\text {st }}$ century BCE (NIKIPROWETZKY, 1970) or, more probably, from the $2^{\text {nd }}$ century $\mathrm{BCE}^{8}$ during the reign to Ptolemy VI Philometor, between 163-45 BCE. Egypt is surely its provenance because of the many references to Egypt and to the seventh king of Egypt. It has been located within Alexandrian Judaism but, according to John J. Collins (1983, p. 355), it may rather have been written by the followers of Onias, the founder of the Leontopolis temple, because of the good relations between Jews and gentiles in Egypt during this period.

In verses 573-79, the author explicitly exalts the Jerusalem temple and wants more people to support it

\author{
There will again be a sacred race of pious men \\ Who attend to the counsels and intention of the Most High, \\ Who fully honor the temple of the great God \\ With drink offering and burnt offering and sacred hecatombs, \\ Sacrifices of well-fed bulls, unblemished rams, \\ And firstborn sheep, offering as holocausts fat flocks of lambs \\ On a great altar, in holy manner.
}

And, finally, when the author prophesies that people from all countries will send gifts to the temple, in vv. 715-19 (see also 772ff), he explicitly presents the apologetic purpose of his text. He has in mind the conversion of gentiles and the remaining of Jews inside the sphere of zealous observance of the Law:

${ }^{8}$ Collins, J. J. (1972); Nolland, J. “Sib Or III. 265-94, An Early Maccabean Messianic Oracle,” JTS 30 (1979): 158-67. 
They will bring forth from their mouths a delightful utterance in hymns,

"Come, let us all fall on the ground and entreat

the immortal king, the great eternal God.

Let us send to the Temple, since he alone is sovereign

And let us ponder the law of the Most High God,

Who is most righteous of all throughout the earth. (Vv. 715-19)

Following the passage above is an important piece of evidence of the Jewish antiidolatry propaganda and the use of cheiropoiettois: "But we had wandered from the path of the Immortal./ With mindless spirit we revered things made by hand,/ idols and statues of dead men."

Like book III, Sibyl V is of Egyptian Jewish origin and seems to continue the tradition that was begun in book III. There are, however, significant differences between the two books. The main difference is that the relationship between Jews and gentiles seems to have deteriorated.

The fourth book of the sibylline oracles is a composite work that bears more than one historical level. The first level (corresponding to vv. 49-101) is probably the Hellenistic age, during the early years of the Hellenistic kingdoms (beginning of the $3^{\text {rd }}$ century BCE), for there is no mention of events up to the rise of Rome. The second historical level appears in vv. 1-48, 102-72, and perhaps 173-92. These verses were probably written by Jews during the late $1^{\text {st }}$ century $C E$. The date can be assumed by the last datable event in the book: the eruption of Vesuvius in $79 \mathrm{CE}$.

The lack of references to Egypt does not point toward an Egyptian origin. Neither does its eschatological expectation, which is fairly different from that expressed in Sibyls III and V (usually placed in Egypt): in verses 179-82, God is said to reshape bones and ashes of men so that they may return as mortals again. This is the only evidence in the Jewish books of the sibylline oracles of a belief in resurrection or any form of after-life. Another major difference is the importance it confers to the rite of baptism for salvation. For those reasons, Sibyl IV does not belong to the same group that produced Sibyls III and V but, according to John Collins (1974, p. 380) - following Joseph Thomas (Le movement baptiste en Palestine et 
Syrie (150 av. J.-C.-300 ap. J.-C.) [Gembloux, 1935]) -, it was the work of a Jewish baptismal group in the Jordan valley.

The destruction of the Jerusalem temple is mentioned twice in Sibyl IV. In verse 116, a storm from Italy will destroy "the great Temple of God" and in verses 125-6 the reference is more explicit: "a prince from Rome will destroy the temple of Solomon with fire". The author does not develop the topic as does the one of Sibyl V who, on the other hand, mourns bitterly the destruction of the shrine and predicts ruin for Rome. The indifference of the author with regard to the destruction of the temple is better explained by the rejection of it in the group of verses 1-48. Those verses explicitly present his opinion about the temple:

I am one who utters the oracles not of false Phoebus, whom vain

men called a god, and falsely designated a seer,

but of the great God, whom the hands of men did not fashion

in the likeness of dumb idols made of stone.

For he does not have as a house a stone dragged into a temple

Deaf and toothless, an insult causing great suffering to people,

But one which it is not possible to see from earth, or to be

Measured by mortal eyes, since it was not fashioned by mortal hand.

(Vv. 4-11. Bold text added)

Apparently, the author's criticism is directed at the Jerusalem temple only. But, later, he adds the following:

They will renounce all temples when they see them,

And altars, useless constructions of stones that cannot hear,

Defiled with the blood of animals and sacrifices

Of four-footed creatures. (Vv. 27-30. Bold text added) 
If the author meant to include the Jerusalem temple in verse 27 , then we can infer that he did not really distinguish between the sanctuary in the Holy City and pagan temples in general. John J. Collins (1974, p. 369) understands such identification as a neglect of the temple by the author, not so much a deliberate attack on it, for it did not exist anymore. However, Collins suggests, in the end of his article, that because of their striking resemblance, the group in which the Sibyl IV was written might have probably influenced the Ebionite Christian group. If that was true, he argues (1974, p. 379) "we should infer that the anti-temple tendency was present earlier" than the destruction of the temple in $70 \mathrm{CE}$.

\section{The Epistles of Pseudo-Heraclitus}

The pseudepigraphic epistle is considered to be a literary genre. It is usually attributed to an ancient sage and written for educational and propagandistic purposes (ATTRIDGE, 1976, p. 4-5). According to Harold Attridge (1976, p. 5), "there are several factors within the epistles [of Pseudo-Heraclitus] which support dating them in the period when Cynic epistles were common", which is, around the $1^{\text {st }}$ century CE. Some sections within them are considered to be Jewish material. In his fourth epistle, there are traces of polemic against temples. It has been argued that because of their harshness they were possible interpolations by a Jew or a Christian into the work of a moralist trying to glorify the figure of Heraclitus:

You stupid men, teach us first what god is, so that you may be trusted when you speak of committing impiety. Secondly, where is god? Is he shut up in temples? (en toĩs naoĩs apokekleisménos;) You are a fine sort of pious men, who set up god in darkness! A man takes it as an insult if he is said to be stony; but is a god truly spoken of whose honorific title is "He is born from crags?" You ignorant men, don't you know that god is not wrought by hands (ouk íste hóti ouk ésti theòs cheirótmētos), and has not from the beginning had a pedestal, and does not have a single enclosure? Rather the whole world is his temple, decorated with animals, plants and stars. 
Attridge does not agree with the idea of a Jewish or Christian interpolation because he finds strong evidence of religious intolerance among non-Jewish and non-Christian circles. He concludes by saying that the type of statement that the author of the fourth epistle makes is "the statement of a man who knew and utilized the critique of public cult often made by Cynic and Stoic moralists and who did so, as did some of them, from a distinctly religious point of view" (1976, p. 23).

In accordance with $\mathrm{H}$. Attridge about a possible gentile origin for the fourth epistle of Pseudo-Heraclitus, we argue that the choice of vocabulary also points toward a gentile author. That author, when writing his text, chose the term cheirotmètos to refer to the deity, as it was understood by ignorant men: a god, made by hands, which had a pedestal and a single enclosure, in other words, an idol. If we take into account the fact that, in the Septuagint, the term connected to idols and idolatry was invariably cheiropoietos and that Philo, a pious Jew from Alexandria, when writing about the building of the Jerusalem temple, did rather use the word cheirotmètos so that he would not be misunderstood by his readers, we notice that the author of the fourth epistle was not of Jewish origin. He was not close to the vocabulary of the Jewish Scripture Greek translation as were Hellenistic Jews. The fourth epistle of Pseudo-Heraclitus seems, also for that reason, to be of gentile origin (SELVATICI, 2006, p. 152).

\section{In terms of conclusion}

From what we have seen from the ancient texts and authors analyzed, there are many similar statements against temples and idols both by Hellenistic Jews and, if we take into consideration Harold Attridge's position on the fourth epistle of Pseudo-Heraclitus, gentiles familiar with Cynic and Stoic philosophy. There is at least one Hellenistic Jewish text that presents rejection of the Jerusalem temple cult in very similar words to the ones used in the texts attacking gentile idolatry: the fourth book of the Sibylline Oracles. However, Sibyl IV was written after the destruction of the temple, which minimizes its importance as an evidence for such negative opinion regarding the Jerusalem temple during Stephen's days, in the first half of the $1^{\text {st }}$ century CE. John J. Collins (1974, p. 378-80) suggests, though, that the group from which Sibyl IV originated might have been already preaching baptism of repentance and its critical position towards the temple before $70 \mathrm{CE}$, possibly in the Jordan valley. Philo, on the other hand, is a good example of ethical interpretation of Jewish tradition but when it comes to real following of the Torah he is a faithful observant. 
In a general overview of Hellenistic Judaism during the turning of the era, ethical interpretation of Jewish ritualistic is found in other texts such as Pseudo-Phocylides, Pseudo-Aristeas, the Testament of the Twelve Patriarchs (besides Philo and the Jewish sibylline oracles) due to an affinity with the thought of $1^{\text {st }}$ century Stoicism and, in a larger scale, with Greek philosophy that, since the fifth century BCE, had been presenting "a growing tendency toward monotheism" (COLLINS, 1997, p. 212). According to C. K. Barrett, some of the Diaspora Jews could have thought of the distant Jerusalem temple as something unnecessary but "the difficulty is that we cannot parallel this thought, and in particular this way of interpreting and using Isa. 66:1 in Hellenistic Jewish sources" (1991, p. 365). John J. Collins (1974, p. 379) agrees when he says that such a rejection of the temple cult like the one present in the fourth Sibyl was to be found only in Christian groups but, most radically, in Acts 7:48.

In order to point towards a conclusion, we should return to the text of Acts and focus on the third charge laid by the false witnesses on Stephen. They accuse him of saying that "Jesus the Nazorean will destroy this place and change the customs that Moses handed down to us" (6:14). In fact, something important to bear in mind is that the main source or first spark for Stephen's major criticism of the temple as idolatry must have been Jesus himself. It may sound obvious to say that, but it is necessary after all.

Much has been written on Jesus' attitude towards the Jerusalem temple. Bertil Gärtner believed in 1965, from the Synoptic gospels, especially Mt. 18:20 ("For where two or three are gathered in my name, there am I in the midst of them"), that Jesus really criticized the cult of the temple, but did not urge its abolition, and in that he was in line with the Qumran tradition. According to the author, Jesus
transferred the activities of the Temple from Jerusalem to another entity. This entity was Jesus himself and the group around him as Messiah... [In that way], the presence of God would no longer be linked with the temple, but with him and those whom he had gathered to himself. (1965, p. 114)

ater on he added, "it is this transference of the 'presence' of God in the temple and its cultus that Qumran and the New Testament have in common": Men + a fellowship = spiritual temple.

Recent scholarship has been more careful in attributing to Jesus all those Christological ideas that evolved from the events of his life, death and supposed resurrection and were later reshaped and developed. Emphasizing the importance of narrative, Steve Smith (2017) employs an intertextual approach when he reads Stephen's speech in Acts in relation to 
Jesus' laments over Jerusalem in the third gospel (Lk 13:31-35). The author highlights the continuity of theme between the two books. He affirms:

Exilic language in the [Jesus'] laments also implicitly associates the destruction of the city with covenant unfaithfulness. (...) Covenant unfaithfulness is made explicit in Acts 7:51, 53, where it is associated with idolatry as well as Jesus' death. (SMITH, 2017, p. 191)

Smith, then, infers what ancient readers of Luke-Acts would have concluded of the episodes of Jesus' laments and Stephen's speech after reading the whole of Lukan twovolume work:

Stephen makes a counter-accusation of idolatry against his opponents and this was an important trigger to his death. By implication, it was a significant aspect in the rejection of Jesus the prophet as well. (...) The association of these texts together in the mind of the reader causes a reexamination of Jesus' message, and a realization that concerns about idolatry have formed a significant part of Jesus's criticism of Temple practice (SMITH, 2017, p. 191).

Adela Yarbro Collins, employing a historical critical approach, argues in favor of very down to earth (in terms of a Jewish background) possible reasons for Jesus' action in Herod's temple, when he expels the dove sellers and money changers from the outer court of the sanctuary. Her hypothesis is that

his action against those who were selling doves indicates his advocacy of an ideal Temple along the lines of those depicted by Ezekiel and the Temple Scroll. The outer court was to be sacred space devoted to prayer and teaching, not civic space open to the general public and devoted to profane activities (YARBRO COLLINS, 2001: 58).

The author's idea, when compared to the elements present in Stephen's speech, parallels:

a)Stephen's emphasis on the holiness of the simple tabernacle erected under God's instruction (bold text added);

b)-the fact that God does not dwell in houses made by human hands, especially those humans who have corrupted the ideal notion of the presence of God among his people and 
built him, "reveling in the work of their hands", a big and rich palace that looked like a kaisareion ${ }^{9}$ and in which all kinds of profane activities were conducted!

The Jerusalem Temple was, definitely, idolatry in the eyes of Stephen. And on gentile idolatry, he must have had hundreds of Hellenistic Jewish texts besides Cynic and Stoic texts to be inspired by.

\section{Bibliography}

ATTRIDGE, Harold W. First-Century Cynicism in the Epistles of Heraclitus. Missoula: Scholars Press (Harvard Theological Review), 1976.

BARCLAY, John M. G. Jews in the Mediterranean Diaspora. From Alexander to Trajan (323 BCE117 CE). Edinburgh: T\&T Clark, 1996.

BARKER, Margaret. Temple Imagery in Philo: An Indication of the Origin of the Logos?, in: HORBURY, W. (ed.) JSNT Supplement Series 48: Templum Amicitiae. Essays on the Second Temple presented to Ernst Bammel. Sheffield: Sheffield Academic Press, 1991, pp. 70-102.

BARRETT, Charles K. Attitudes to the Temple in the Acts of the Apostles, in: HORBURY, W. (ed.) JSNT Supplement Series 48: Templum Amicitiae. Essays on the Second Temple presented to Ernst Bammel. Sheffield: Sheffield Academic Press, 1991, pp. 345-367.

T Clark, 1994, vol. 1.

The International Critical Commentary: Acts of the Apostles. Edinburgh: T \&

COLLINS, John J. The Sibylline Oracles of Egyptian Judaism. Missoula: Society of Biblical Literature for the Pseudepigrapha Group, 1972.

. The Place of the Fourth Sibyl in the Development of the Jewish Sibyllina, Journal of Jewish Studies 25 (1974), pp. 365-80.

Sibylline Oracles, in: CHARLESWORTH, J. T. The Old Testament Pseudepigrapha, 1: Apocalyptic Literature \& Testaments. Garden City, NY: Doubleday, 1983, pp. 362-531.

Jewish Wisdom in the Hellenistic Age. Edinburgh: T\&T Clark, 1997.

Epistles of Pseudo-Heraclitus, in: ATTRIDGE, H. W. First-Century Cynicism in the Epistles of Heraclitus. Missoula: Scholars Press (Harvard Theological Review), 1976.

FITZMYER, Joseph. The Anchor Bible: The Acts of the Apostles. A New Translation with Introduction and Commentary. New York: Doubleday, 1998.

HENGEL, Martin. Judaism and Hellenism: Studies in their encounter in Palestine during the early Hellenistic period. Philadelphia: Fortress Press, 2 vols, 1974.

${ }_{9}$ Yarbro Collins (2001: 57) explains that Herod the great's plan for the temple mount ensemble (significantly enlarged by him) had similarities to an Egyptian-Hellenistic Stoa type of fortress dedicated to the sovereign's cult. The author stresses the fact that this form of architecture was adopted by Julius Caesar and Cleopatra for the Kaisareion, a building complex dedicated to the cult of Caesar in Alexandria. 
GÄRTNER, Bertil. The Temple and the Community in Qumran and the New Testament. A Comparative study in the Temple symbolism of the Qumran texts and the New Testament. Cambridge: Cambridge University Press, 1965.

GAVENTA, Beverly R. Toward a Theology of Acts: Reading and Rereading, Interpretation 42 (1988), pp. 146-57.

GRUEN, Erich S. Heritage and Hellenism: the reinvention of Jewish tradition. Berkeley: University of California Press, 1998.

HADAS-LEBEL, Mireille (Ed.) Philo of Alexandria: A Thinker in the Jewish Diaspora. Leiden: Brill, 2012.

MEEKS, Wayne A. (gen. ed.) The HarperCollins Study Bible: New Revised Standard Version, with the Apocraphal / Deuterocanonical books. San Francisco: HarperSanFrancisco, c1993.

NESTLE-ALAND. Novum Testamentum Graece. Stuttgart: Deutsche Bibelgesellschaft, 1993.

NIKIPROWETZKY, Valentin. La Troisième Sibylle. Paris: La Haye, 1970.

PHILO OF ALEXANDRIA, in: Loeb Classical Library, with an English translation by F. H. Colson and G. H. Whitaker. London, Heinemann; New York, Putnam, 1929-1962.

SANDELIN, Karl-Gustav. Review of P.V. Legarth, Guds Tempel. Tempelsymbolisme og kristologi hos Ignatius af Antiokia. In: RUNIA, David T. Philo of Alexandria: an annotated bibliography, 1987-1996: with addenda for 1937-1986; with the assistance of H.M. Keizer and in collaboration with the International Philo Bibliography Project. Leiden: Brill, 2000, p. 167.

SELVATICI, Monica. Os Judeus Helenistas e a Primeira Expansão Cristã. Questões de Narrativa, Visibilidade Histórica e Etnicidade no Livro de Atos dos Apóstolos. (Ph.D. Dissertation in History). Campinas, UNICAMP, 2006.

Sibylline Oracles Books III, IV and V, in: CHARLESWORTH, J. T. The Old Testament Pseudepigrapha, 1: Apocalyptic Literature \& Testaments. Garden City, NY: Doubleday, 1983, pp. 362-531.

SMITH, Steve. The Fate of the Jerusalem Temple in Luke-Acts: An Intertextual Approach to Jesus' Laments Over Jerusalem and Stephen's Speech. London \& New York: Bloomsbury T\&T Clark, 2017.

SWEET, J. P. M. A House Not Made With Hands, in: HORBURY, W. JSNT Supplement Series 48: Templum Amicitiae. Essays on the Second Temple presented to Ernst Bammel. Sheffield: Sheffield Academic Press, 1991, pp. 368-90.

YARBRO COLLINS, Adela. Jesus' Action in Herod's Temple", in: YARBRO COLLINS, A.; MITCHELL, M. M. (eds.) Antiquity and Humanity. Essays on Ancient Religion and Philosophy Presented to Hans Dieter Betz on his 70 ${ }^{\text {th }}$ Birthday. Mohr Siebeck, 2001, pp. 45-61.

Recebido em: 01-11-2017

Aceito em: 26-12-2017 